\title{
Study of paleochannels by means of gravimetric observations
}

\author{
Leonid M. Budanov ${ }^{1}$ \\ Natalia P. Senchina*2 \\ Olga M. Shnyukova ${ }^{2}$ \\ Gleb D. Gorelik ${ }^{2}$
}

\author{
${ }^{1}$ A.P. Karpinsky Russian Geological Research Institute, \\ St. Petersburg, Russia \\ ${ }^{2}$ Saint Petersburg Mining University, St. Petersburg, Russia \\ *E-mail: $\underline{\text { n_senchina@inbox.ru }}$
}

\section{Abstract Pезюме RUS}

Investigation of ancient river valleys - paleochannels - is of particular relevance for the territory of St. Petersburg and the Leningrad region due to a poor stability of rocky soils here and the subsequent high risk of structural damage during the construction of multi-storey buildings. In addition, paleochannels in the region constitute a source of renewable drinking water owing to a significant capacity of sandy sediments. The mapping and estimation of the capacity of such reservoirs may be useful for the selection and monitoring during operation of water sources feeding the nearest settlements (Sestroretsk, Solnechnoye, etc.). Since the density of the enclosing rocks is higher than that of incising sediments, paleochannels constitute areas having a relatively high thickness of low-density sediments, over which negative gravimetric anomalies can be expected. At the first stage of the study, observations along a single profile crossing the assumed position of the paleochannel under study were performed. The study was conducted using a high-precision gravimeter Autograv CG-5 with geodesic tracking. The research confirmed the efficiency of gravity survey for solving the research tasks, as well as for performing areal gravimetric observations combined with shallow seismic surveys. The anomaly above the incision under study was approximately $1 \mathrm{mGa}$. The study revealed the presence of tectonic disruptions under the paleochannel, vertically displaced respective to the underlying sediments not inherited by the modern relief. Observations, processing and interpretation of the data were performed with the participation of students from the St. Petersburg Mining University in the framework of elective classes.

\section{Keywords}

gravimeter, gravity survey, Bouguer reduction, gravitational field, paleo-bed, paleo-valley, engineering geophysics, Gulf of Finland, Leningrad region, glacial deposits

For citation: Budanov L.M., Senchina N.P., Shnyukova O.M., Gorelik G.D. Study of paleochannels by means of gravimetric observations. Geosistemy perehodnykh zon = Geosystems of Transition Zones, 2020, vol. 4, no. 3, pp. 288-296 (In Russ.). https://doi.org/10.30730/gtrz.2020.4.3.288-296

Для цитирования: Буданов Л.М., Сенчина Н.П., Шнюкова О.М., Горелик Г.Д. Исследование палеовреза с помощью гравиметрических наблюдений. Геосистемы переходных зон, 2020, т. 4, № 3 , c. 288-296. https://doi.org/10.30730/gtrz.2020.4.3.288-296

\section{References}

1. Auslender V.G., Ianovskii A.S., Kabakov L.G., Pleshivtseva E.S. 2002. Novoe v geologii Sankt-Peterburga [New in geology of Saint Petersburg]. Mineral, 1(4): 51-58. (In Russ.).

2. Budanov L.M., Glazunov V.V., Sergeev A.Yu., Kropachev Yu.P. 2017. Kartirovanie pogrebennykh dolin v predelakh akvatorii ozera Sestroretskii Razliv po dannym kompleksnykh gidrogeofizicheskikh issledovanii [Mapping of the buried valleys within the water area of the Sestroretsky Lake Spill according to the data of complex hydrogeophysical 
studies]. In: Materialy 13-i konferentsii $i$ vystavki “Engineering Geophysics 2017” [13th Conference and Exhibition “Engineering Geophysics 2017”]. Kislovodsk, 190-198. (In Russ.).

3. Climate Proof Living Environment. URL: http://cliplive.infoeco.ru/index.php?id=34 (accessed 05.05.2020).

4. Dashko R.E., Aleksandrova O.Yu., Kotiukov P.V., Shidlovskaia A.V. 2011. Osobennosti inzhenerno-geologicheskikh uslovii Sankt-Peterburga [Features of geotechnical conditions of St. Petersburg]. In: [Urban development and geotechnical construction], 1: 1-47. (In Russ.). http://www.urban-development.ru/2011/2.pdf

5. Geological Atlas of Saint Petersburg. 2009. St. Petersburg: Komilfo, 57 p. (In Russ.).

6. Huuse M., Lykke-Andersen H. 2000. Overdeeped Quatearnary valleys in the eastern Danish North Sea: morhpology and origin. Quatearnary Science Reviews, 19: 1233-1253. https://doi.org/10.1016/s0277-3791(99)00103-1

7. Jørgensen F., Sandersen P.B.E. 2008. Mapping of buried tunnel valleys in Denmark: new perspectives for the interpretation of the Quaternary succession. Geological Survey of Denmark and Greenland (GEUS) Bulletin, 15: 3336. https://doi.org/10.34194/geusb.v15.5037

8. Malov N.D. 1999. O prichinakh avarii v Peterburgskom metro [About the causes of the accident in the St. Petersburg metro]. Mineral, 2(3): 44-47. (In Russ.).

9. Nikolaeva T.N., Norova L.P. 2012. Inzhenerno-geologicheskaia otsenka osobennostei stroeniia drevnei doliny na severe Sankt-Peterburga [Engineering geological assessment of the features of the structure of the ancient valley in the north of St. Petersburg]. Gruntovedenie [Soil Science], 1: 44-52. (In Russ.).

10. Reinhard K., Rumpel H.-M., Scheer W., Wiederhold H. 2006. Groundwater resources in buried valleys - a challenge for geosciences. Hannover: Leibniz Inst. for Applied Geosciences (GGA-Institut), 299 p.

11. Spiridonov M.S. et al. 2010. Atlas geologicheskikh i ekologo-geologicheskikh kart Rossiiskogo sektora Baltiiskogo moria [Atlas of geological and ecological-geological maps of the Russian sector of the Baltic Sea]. St. Petersburg: VSEGEI, 78 p. (In Russ.).

12. Velegrakis A.F., Ballay A., Poulos S., Radzevičius R., Bellec V.K., Manso F. 2010. European marine aggregates resources: Origins, usage, prospecting and dredging techniques. J. of Coastal Research, SI, 51: 1-14.

13. Yaduta V.A. 2006. Noveishaia tektonika Sankt-Peterburga i Leningradskoi oblasti [The latest tectonics of St. Petersburg and the Leningrad region]. Mineral, 1: 28-35. (In Russ.). 